\title{
ASTRONOMICAL CAUSES OF CLIMATE CHANGE. MILANKOVIĆ-BACSÁK CYCLE AND THE LAST ICE AGE
}

\author{
A HÁGEN \\ Elementary school Felsőszentiván. Szent István u. 19., 6447 Felsöszentiván, Hungary \\ E-mail: hagena@freemail.hu
}

\begin{abstract}
Summary: György Bacsák, a Hungarian polyhistor, was born 150 years ago and died 50 years ago. He played an important role in refining and further developing the Milanković cycle. Milanković's theory describes the effect of changes in Earth's movements on the climate. The theory came from its creator, Milutin Milanković, a Serbian geophysicist and astronomer. The Serbian scientist was imprisoned in the Austro-Hungarian Monarchy during World War I as a citizen of a hostile state. He developed his theory in the library of the Hungarian Academy of Sciences. Understanding the essence of the theory, György Bacsák enjoyed the theoretical support of Milanković in the form of regular correspondence between 1938 and 1955. In total, György Bacsák wrote 56 letters to Milutin Milanković, while the Serbian scholar wrote 10 letters, all of which can be found in the Library of the Hungarian Academy of Sciences. The language of the letters was German, since both Bacsák and Milanković spoke German fluently. Three articles from György Bacsák, from the year 1940, were published in the Magazine "Weather" and a part of his book "Earth's history of the last 600,000 years" was published in 1944 both of them were based on this letter exchange.
\end{abstract}

Key words: Milutin Milanković, György Bacsák, letter exchange, interglacial, interference

\section{INTRODUCTION}

In the 19th century, the geologists began to recognize that there had been several glaciations in recent millennia. Dominantly, the glaciations originated in Scandinavia and extended all the way to the southern foot of the Alps. As the traces of the ice ages are more separated on the ridges of the Alps than in the northern plains, its names are derived from the signs there. Over the past 600,000 years, there have been four major ice ages, each with multiple peaks of glaciation. At the time of the greatest glaciation, the ice sheet occupied $9 \%$ of the Earth's surface. Today, the permanent ice cover is 3\%.

Researchers of the century were puzzled by the problem because they believed for a long time that the climate of our Earth was constant, as written history testifies to this.

In the early 20th century, the researchers came to the conclusion that many cubic kilometres of continuous occurrence, in the reduction of differences between the seasons are not introduced into the general cooling down, but mild winters and cool summers ice accumulation of thousands of years. Since the seasons are caused by the deviation of the angle between the Earth's axis of rotation and the plane of the solar circuit from the perpendicular, an explanation for the icing can be found in the change in the angle of rotation. This angle of inclination is one of the elements of the Earth's orbit. The change in orbital elements is caused by the disturbing gravitational effect of the other planets (Major 2006, Hágen 2013, Szarka 2020). 


\section{SHORT BIOGRAPHY OF MILUTIN MILANKOVIĆ}

Milutin Milanković (Figs. 1, 2) was born in 1879 as a child of a relatively wealthy Serbian family near the village of Dálya on the banks of the Danube near Osijek.

Due to the relative affluence, there was a kind of obligation to obtain a higher education degree and to continue the family business. For this reason he studied agriculture, but was still attracted to the natural sciences. Milanković make the PhD disertation at 1903 and he was the first Serbian doctor of science in technical sciences.

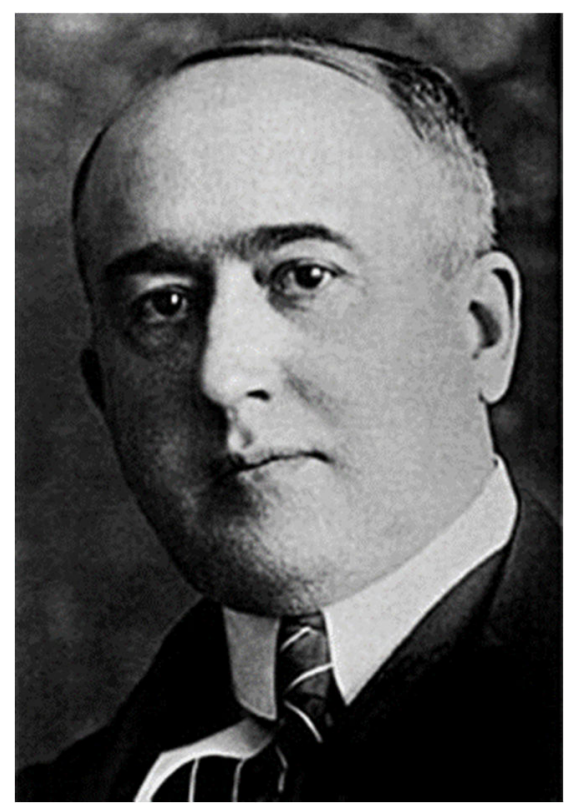

Fig. 1 Milutin Milanković

He returned to Belgrade in five years as a professor of Mathematics at the university there. His main perspective was primarily research, so he was constantly looking for problems. In 1911 he hosted a friend with whom he had a wine, and it was then that he came up with the idea of putting into mathematical form the connection between climate change and the movement of the planets in the Solar System.

The professor studied the studies previously written. He was in constant consultation with the German mathematician Ludwig Pilgrim, whose work was published in 1904, which contained calculation parameters for the Earth's axial skew and its rotation about an axis. Pilgrim also tried to find connections between orbital elements and ice ages.

Milutin Milanković began looking for these reasons at the University of Belgrade. In the summer of 1914, he was in the territory of the Austro-Hungarian Monarchy, when World War I broke out, and as a Serbian citizen he and his wife were interned by the authorities of the Monarchy. He moved to Budapest soon, where he continued his research in the library of the Hungarian Academy of Sciences and in the mathematics department (Hágen 2013). 


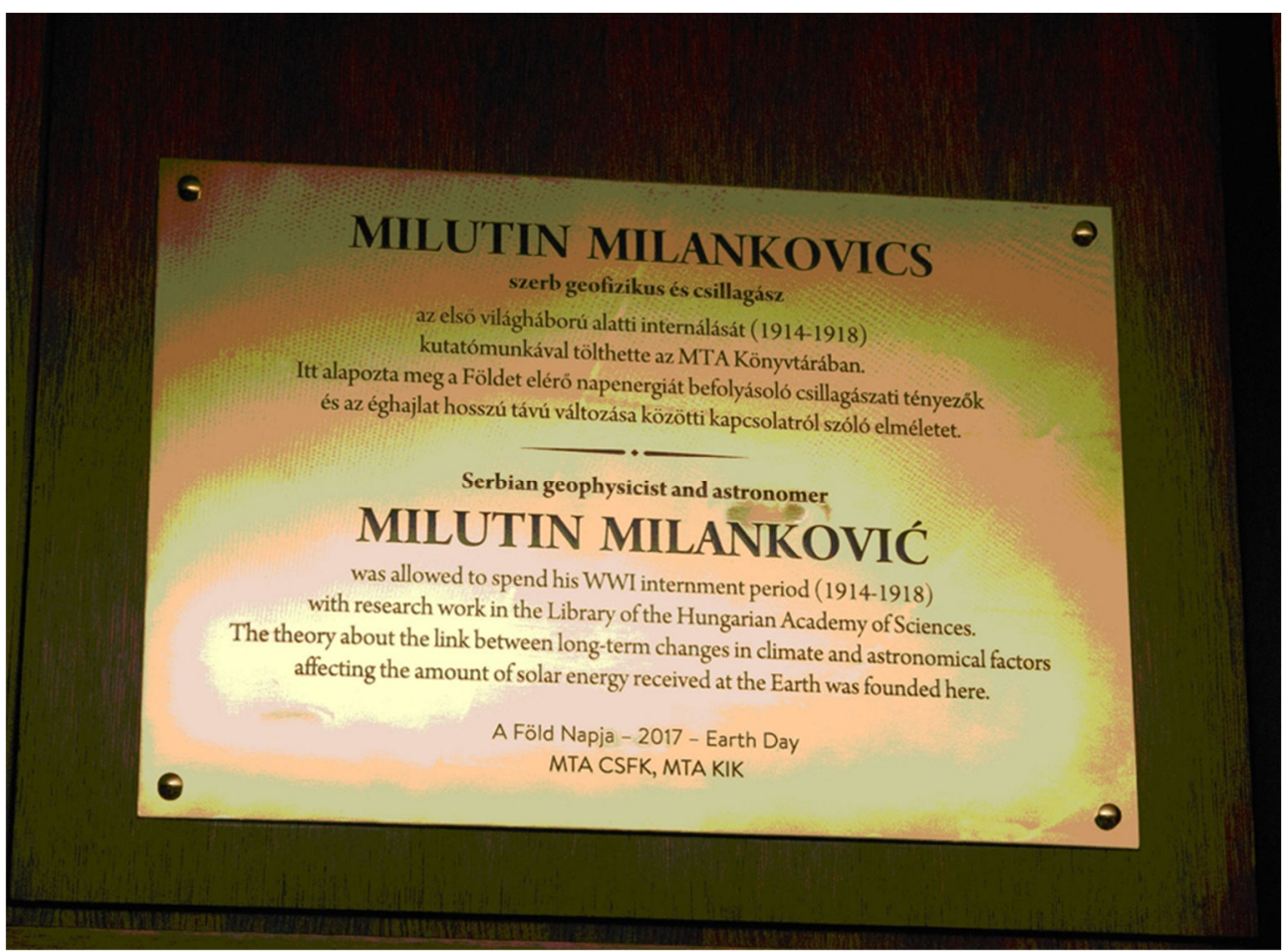

Fig. 2 Memorial plaque in honor of Milutin Milanković placed on April 20, 2017 in the library of the Hungarian Academy of Sciences

\section{MILANKOVIĆ-BACSÁK CYCLE}

By the second year of World War II, he was pretty much done with the monograph. He expected the war to end soon and he could publish his work. The cataclysm dragged on, so it was not until 1920 that he was able to publish his work in French (Fig. 3). According to him, astronomical rhythm regulation has three components.

The first is the angle of inclination of the Earth's axis of rotation (Fig. 4). The direction of the axis of rotation is currently at an angle of $23.5^{\circ}$ with the perpendicular to the plane of the Earth's orbit. This angle fluctuates between $21.5^{\circ}$ and $24.5^{\circ}$ degrees over a period of 41,000 years. The greater the angle of inclination, the more extreme the seasons in both hemispheres: summers are warmer and winters are colder.

The second component is the shape of the Earth's orbit, which changes over a period of 100,000 years (Fig. 4). It stretches once and takes the shape of an ellipse with high eccentricity, then becomes almost circular again. As the eccentricity increases, the difference between the minimum and maximum distances between the Sun and the Earth increases. Currently, the Earth moves away from the Sun the most when there is winter in the southern hemisphere, resulting in a slightly colder winter in the southern hemisphere and a slightly warmer summer than in the northern hemisphere. 
The third component is precession, that is, the displacement of the Earth's axis due to the torque of the Sun and the Moon (Fig. 4). The axis of rotation describes a complete circle relative to the stars in 23,000 years. Precession determines whether summer in a given hemisphere falls at the near-day or far-day point of the Earth's orbit, that is, whether the seasonality of the Earth's climate due to axis skew is strengthened or weakened by seasonality due to orbit eccentricity. If these two determinants of seasonality (axis skew and orbital eccentricity) are in sync with each other on one hemisphere, they must be asynchronous on the opposite hemisphere. So, projected onto the area of the two poles, the icing cycles are opposite.

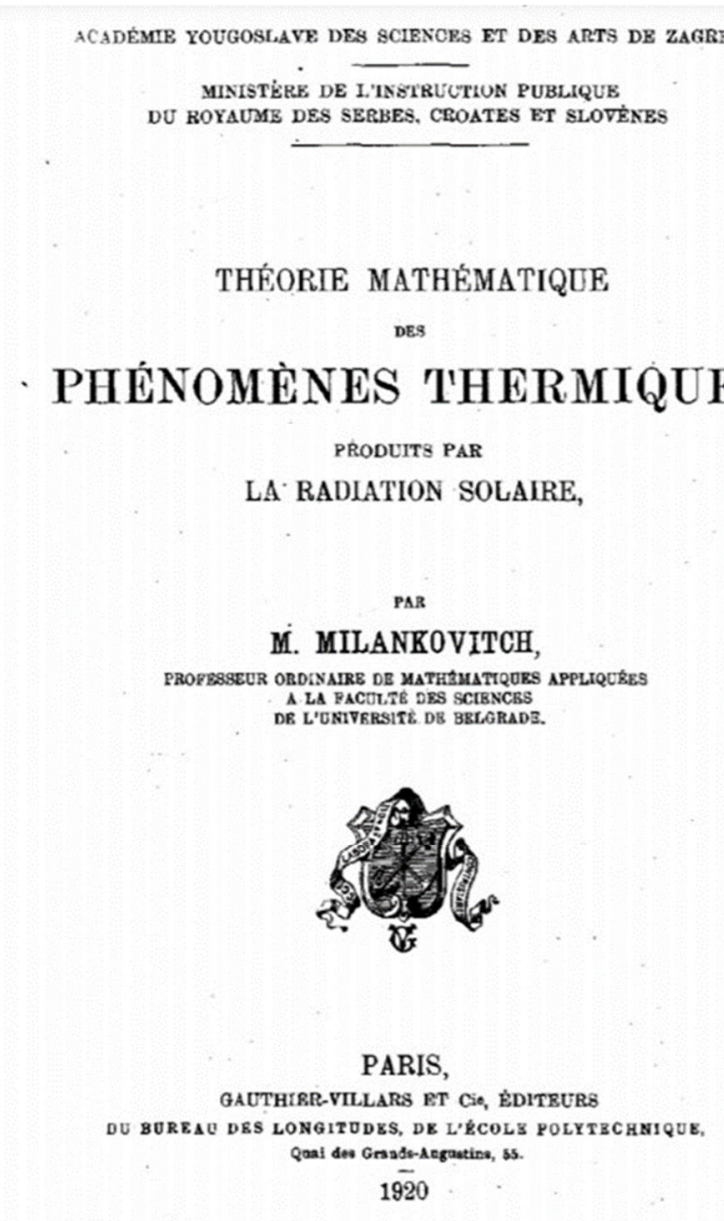

Fig. 3 Cover of Milanković's book

Milanković calculated that the combined effect of these three factors would change the amount of summer solar radiation near the northern corner by up to $20 \%$. This, in turn, may be reason enough for the ice field covering the northern part of the northern hemisphere to advance as cool summers and mild winters alternate. 
He organized the research of the Serbian scientist and summarized it in a table. In Milanković's table, he focused on the 9 glacial peaks listed, all of which did not account for a sixth of a 600,000-year period, and did not pay attention to the interglacials that filled the larger part.

György Bacsák, blessed with excellent mathematical senses, became the first to understand, explain and apply it. He was not involved in developing the theory. Basically, the study of interglacials and the application of precise mathematical apparatus can be added to the name of Bacsák. This is how the Milanković-Bacsák cycle used in the Hungarianspeaking world was created, because globally it is only called the Milanković cycle.

Milanković's theory had to be explained because he has never described in sufficient detail the astronomical and astronomical foundations of the theory, for which the calculations were carried out by one of his colleagues, Vojislav Misković. On the other hand, Milanković was quite difficult to articulate, so he gave the opportunity for misunderstandings.

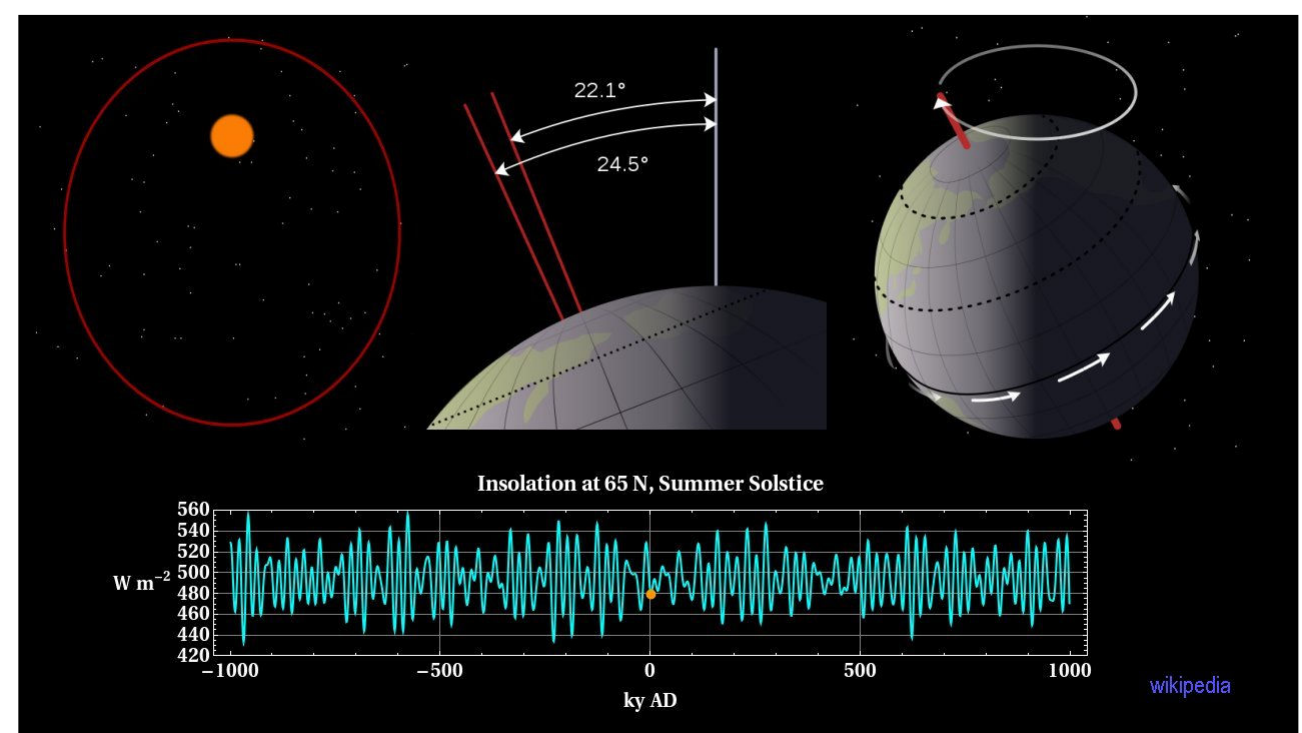

Fig. 4 Illustration of the eccentricity, the obliquity and the climatic precession. Bottom: Insolation at the geographical latitude of $65^{\circ} \mathrm{N}$, at the Summer Solstice of the past one million years and the next one million years (Szarka 2020)

\section{SHORT BIOGRAPHY OF GYÖRGY BACSÁK}

The famous Hungarian scientist (Fig. 5) was born in Bratislava in 1870. He completed his schools in German language in Bratislava. He obtained a doctorate in law from the Pázmány Péter University in Budapest. After the World War I, first he went to Hörcsök in Fejér County and then to Fonyód in Somogy County. 


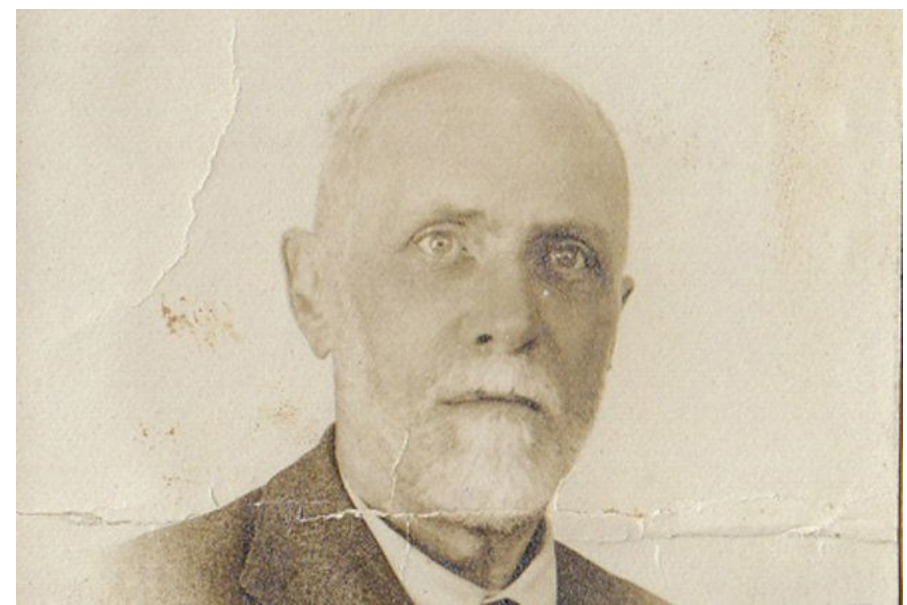

Fig. 5 György Bacsák

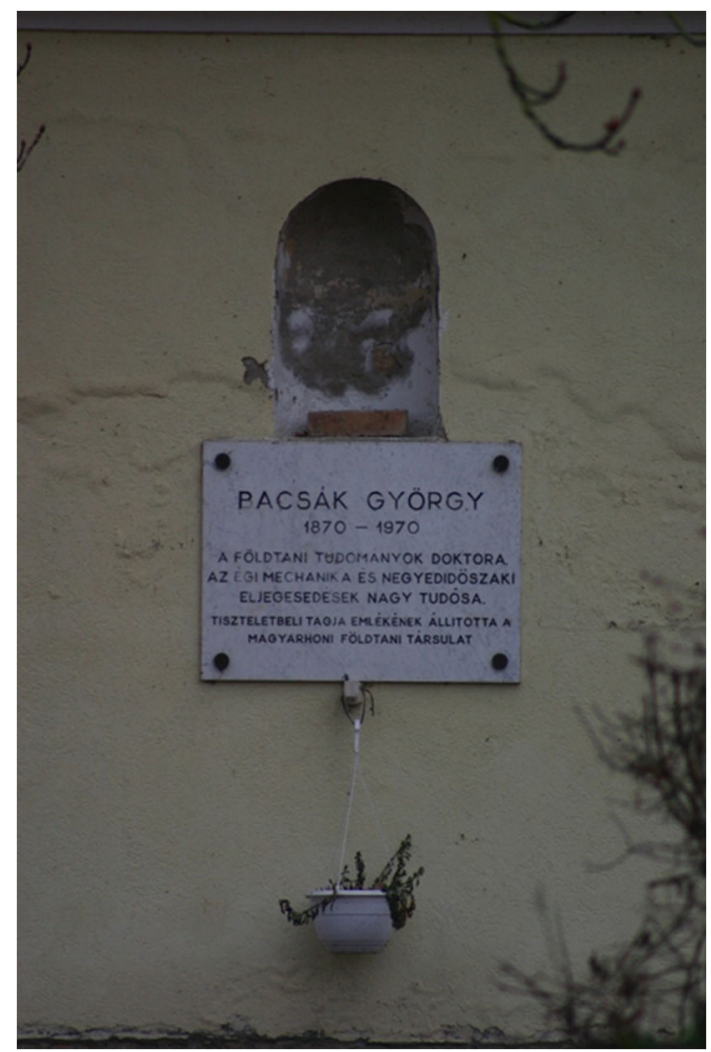

Fig. 6 Memorial plaque of György Bacsák in Fonyód

He spent most of his time away from the cities in his villa in Fonyód (Fig. 6). He always got up early, went to bed late, and was aware of that intense physical work and proper 
sports were an essential complement to deepened mental activity. He also practiced this refreshing course on a daily basis (Gádoros 1970).

He embraced astronomical knowledge in a self-taught way, supplemented by his extensive knowledge of mathematics, which played a significant role in his knowledge and application of Milutin Milanković's theory of the celestial mechanics of climate change. Unfortunately, he published his results on climate change very late - at the age of 70 years. In response to the request of the Hungarian Academy of Sciences, he submitted his dissertation in 1954 at the age of 85 (!) on the causes of the Ice Age. He defended his dissertation so successfully that he was immediately awarded the title of Doctor of Mineral Sciences.

Bacsák provided lasting not only in the research of the ice ages, but also in the excavation and rescue of the archaeological monuments of Fonyód (Hungary).

The famous Hungarian polyhistor lived a long time, perhaps due to his love of sport or his cheerful nature he died on March 4, 1970, three months before his 100th birthday.

György Bacsák is also remembered with great respect by the Hungarian Geological Society and the Hungarian Geographical Society. These two organizations placed a plaque on the scientist's house in Fonyód (Fig. 6). The Department of Earth Sciences of the Hungarian Academy of Sciences held a commemoration in 1997 (Major 2006).

In the following, let us become acquainted with the three letters with which he made his name in the history of paleoclimatological researchers.

\section{DETAILS FROM GYÖRGY BACSÁK'S 1938 LETTER}

Between 1938 and 1955, György Bacsák enjoyed Milanković's theoretical support in the form of regular correspondence. In total, György Bacsák wrote 56 letters to Milutin Milanković, while the Serbian scientist wrote 10 letters, all of which can be found in the Library of the Hungarian Academy of Sciences and the Library of the Serbian Academy of Sciences. The language of the letters was German, as both Bacsák and Milanković were fluent in German.

A sketch of a later publication can also be found in Bacsák's letter written in 1938 (Bacsák 1938).

"When I read your classic work "Mathematical Climate and Astronomical Theorie der Klimaschwankungen" and what he had to say in 1933, I immediately turned my attention to Misković's chart and excitedly awaited the publication of Guttenberg's Geophysics, Volume 8, where on page 124, I hoped for a better approach. To date, I have not been able to obtain this book. However, I managed to get the CLIII Paper through the Royal Serbian Academy. Booklet, which revealed that my intuitions that the delta value of the -0.0234 and -0.0239 values used at 465 and $465.4(\mathrm{t})$ in Table 13 were incorrect were correct..."

Bacsák drew Milanković's attention to a typographical error, in return for asking the Serbian professor to investigate Bacsák's questions and try to answer them as well.

"If we place the curves of $\varepsilon$ (Earth's axis of rotation) and e $\sin \pi$ (precession) at the appropriate parts on the bases of Graphic Table 13 and add the coordinates obtained, we obtain a curve that is similar to the smaller inversion in Table II with the curves shown on the board. Because we are European archaeologists, we are primarily interested in the critical geographical areas between the Alps and Scandinavia, so it may be permissible for us to use this single climate curve as a calendar." (Fig. 7) 


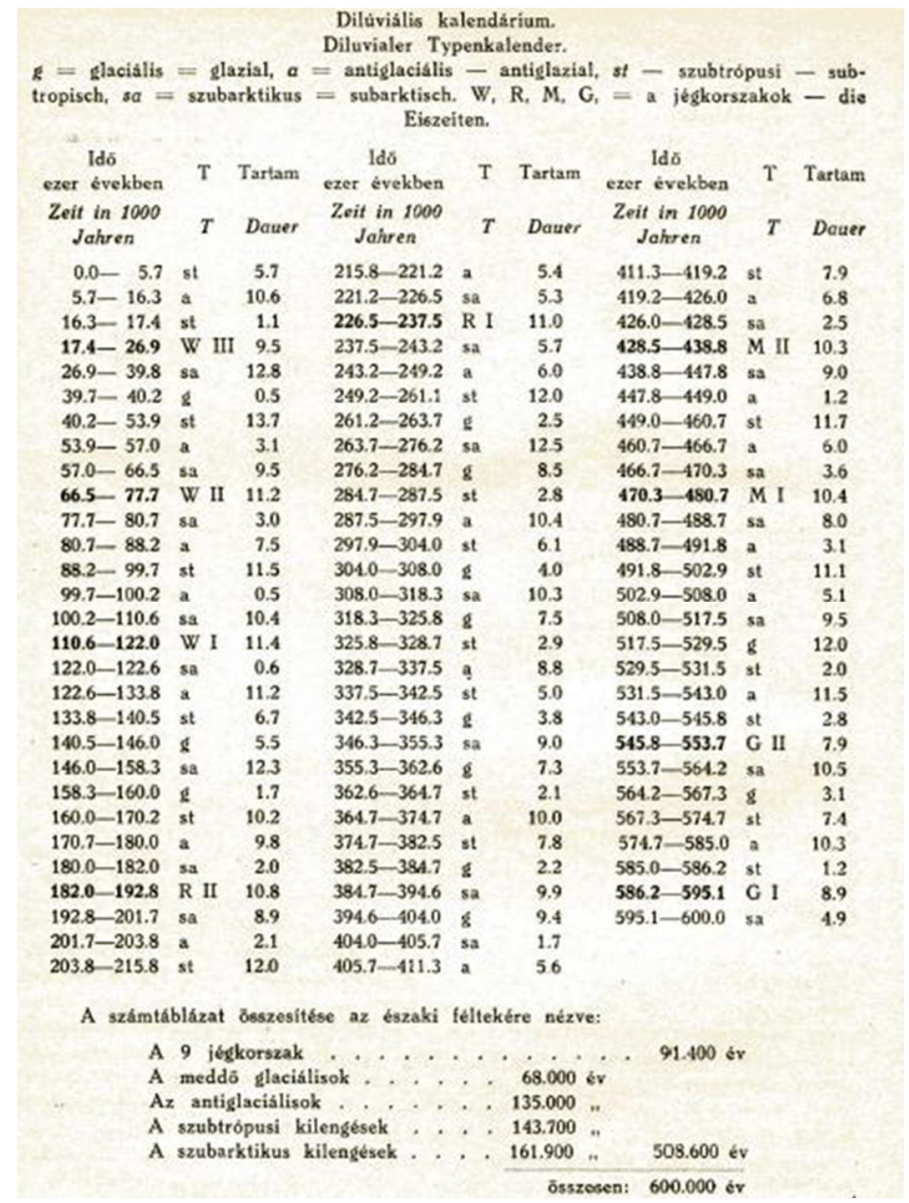

Fig. 7 Diluvial calendar (Bacsák 1940a)

After the calendar, György Bacsák turned much more towards the interglacials. Thus, his second question has already much more related to the Ice Age.

"By ice ages alone, we can in no way bring order to the horrific jungle of archaeologist's chronology. However, it would clearly help us to address the interglacial parts in the climatic stages. I envision this very schematically as follows:

I would put this formula, $\Delta$ (e $\sin \pi$ ) [the precession] before everything else, so that the contrasts between the seasons show a rhythmicity of 21,000 years. Meanwhile, the role of $\varepsilon$ [the angle of inclination of the Earth's axis of rotation] remains, according to which the average temperature rises and falls every 40,000 years. Consequently, climate change depends on the interference of these two factors and creates the following four types of climate:

1. The interference of the two curves at the lower peaks creates ice ages (short, wet, pleasant winter, long, cool summer).

2. The interference of the two curves at the upper peaks shows an interglacial climate (long, dry, mild winter, short, hot summer) as well as 10,000, 85,000, 175,000, and so on. 
3. The interference $\Delta \varepsilon$ at the upper culmination and $\Delta(\sin \pi)$ at the lower culmination shows a subtropical climate (humid, short, pleasant winter, long, hot summer), e.g. 47,000, $95,000,210,000$, and so on.

4. The interference gives $\varepsilon$ a subtropical climate at the lower culmination and $\Delta(\sin \pi)$ at the upper culmination (humid, long, cool winter, temperate, short summer), e.g. 150,000, $270,000,310,000$, and so on.

Since the values of $\Delta \varepsilon$ and $\Delta$ (e $\sin \pi)$ are independent of latitudes, a calendar can be created for almost all latitudes as well as for the southern hemisphere (Fig. 7).

From the listed values, György Bacsák made a hand-drawn calendar, which he sent to Milutin Milanković (Fig. 8).

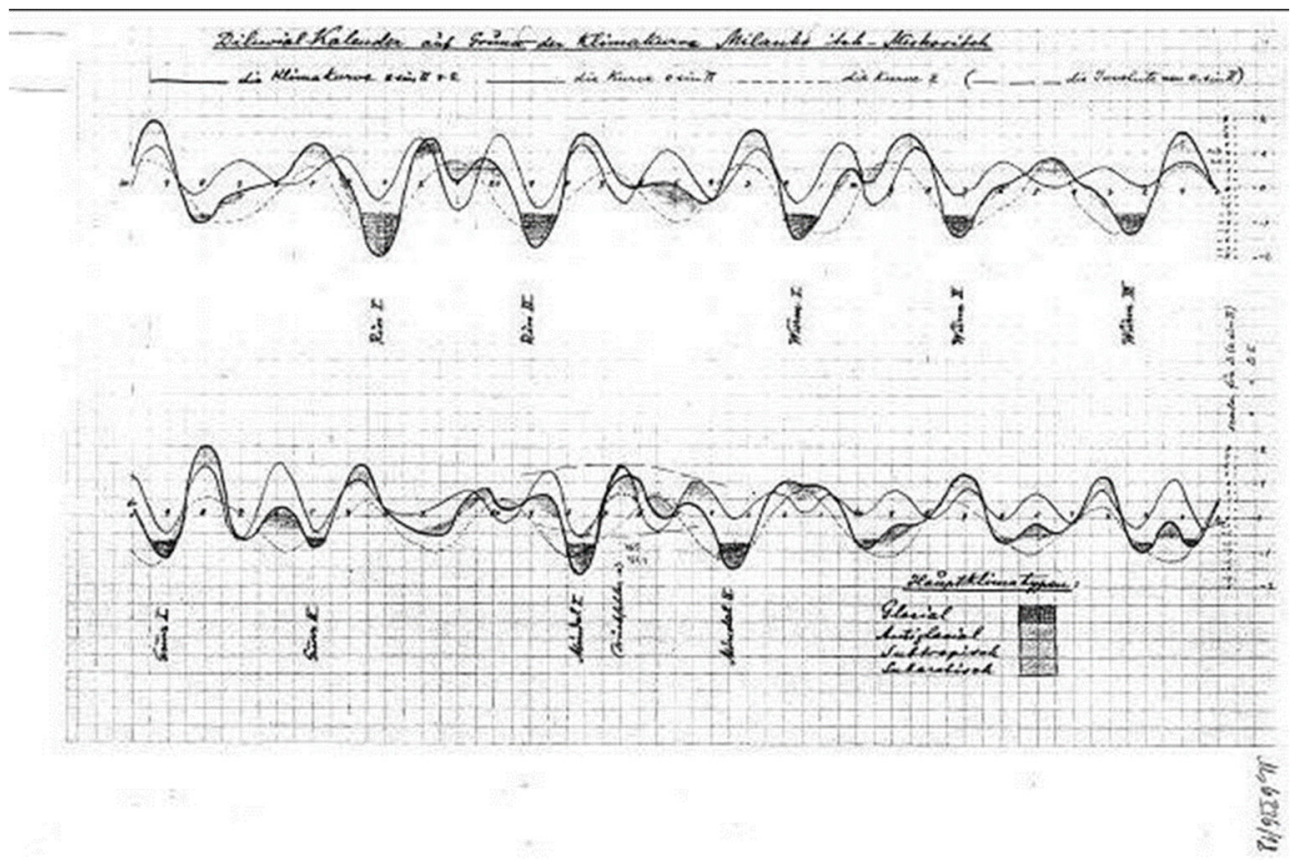

Fig. 8 Hand drawn diluvial calendar (Bacsák 1938)

According to György Bacsák, the transitions between the main climate types are always short due to $\pi$.

"If we view climate change as the interference of the $\varepsilon$ and e $(\sin \pi)$ waves, it is quite easy to determine the interglacial length of the Mindel-Riss.

During this period, the period of $\pi$ was very close to 20,000 years and even $\varepsilon$ held its period of 40000 years..." (Bacsák 1938). This process took place 410,000 years ago, resulting in a subarctic climate, but the same process took place $370,000,330,000$, and 290,000 years ago. These two factors adhered to the appropriate interval, so this may explain the long interglacials.

Bacsák explains in his letter that the rhythm of $\pi$ was between 0-290,000 and 410,000600,000 years different from 20,000 years, so there were several ice ages and quite short 
interglacials. We explain the interference in a similar way in the second, third ice ages, and in the interglacial ones, Riss I and II, Riss II and Würm I, and Würm I and II between.

In the letter, Bacsák explains that the great asymmetry of the ice ages and the ice ages is due to the long period of this $(\sin \pi)$ in the Günz and Mindel periods, i.e., unlike 20,000 years, it lasted 29,000 years here.

\section{POSSIBILITY OF THE MILANKOVIĆ-BACSÁK CYCLE IN SMALLER EVENTS}

Although glacial and interglacial, they occupied a significant period in the history of the Earth. However, research has shown that there are a number of irregular climate fluctuations that appear irregularly, lasting up to a few hundred, but sometimes only for a few decades. These climatic fluctuations are called the Heinrich, Dansgaard-Oeschger, and Bond events by examining the North Atlantic ice wells and seabed glacier sediments.

The cooling periods of the Pleistocene "ice ages", and in particular of the last glacial period of the Würm, which are short-lived and associated with short-term periods of time similar to each other, are called the Heinrich event.

A possible cause is the glacial ice that breaks due to sudden melting, which modifies the "large oceanic conveyor" (Czelnai 1999), resulting in a sudden but short-term decline in the temperature of the northern hemisphere, such as 12,000 years ago (Table 1).

Table 1 Time breakdown of Heinrich events

\begin{tabular}{cc}
\hline „Heinrich event” & Time BP a thousand years \\
\hline H0 & 12 \\
H1 & $16-15$ \\
H2 & $24-22$ \\
H3 & $31-29$ \\
H4 & $38-35$ \\
H5 & 45 \\
\hline
\end{tabular}

The rapid temperature drop was also replaced by a rapid temperature rise. This is called the Dansgaard-Oeschger event. The increase in temperature in Greenland was accompanied by a rapid rise of approximately $10^{\circ} \mathrm{C}$ over $50-100$ years, followed by a slow but continuous cooling (Rousseau and Sima 2014).

Studies in moraine sediments have identified eight climate levels that recur cyclically every 1470 years. This is called a Bond event (Bond et al. 1999). These phenomena, which recur at regular intervals, show a cooling climate cycle. In the last 10,000 years, a number of events have taken place that have determined the evolution of history (Table 2).

The model result can be arrange two main groups. The first main group is the flow results, which can show the quantity of the different flow type. The other main group contains the vegetation processes, and within this, can be distinguish the short vegetation and the tree vegetation type (Table 1). 
Table 2 Bond events and notable historical events

\begin{tabular}{|c|c|c|}
\hline „Bond event” & Time BP a thousand years & Denomination \\
\hline 0 & 0.5 & $\begin{array}{l}\text { A small ice age that played a significant role in the } \\
\text { development of human history }\end{array}$ \\
\hline 1 & 1.4 & age of migrations \\
\hline 2 & 2.8 & $\begin{array}{l}\text { BC early first millennium, the collapse of late Bronze } \\
\text { Age cultures }\end{array}$ \\
\hline 3 & 4.2 & The Old Kingdom of Egypt \\
\hline 4 & 5.9 & $\begin{array}{l}\text { The aftermath of the Neolithic, the Atlantic (it is not a } \\
\text { prehistoric concept of the Atlantic, but rather part of the } \\
\text { biostratigraphic division. At that time, the average } \\
\text { temperature in July was } 17^{\circ} \mathrm{C} \text {, for which there was a } \\
\text { heavy rainfall, the so-called arid climate associated. By } \\
\text { this time, the intensification of human influence in the } \\
\text { environment can be attributed) }\end{array}$ \\
\hline 5 & 8.2 & "Biblical floods" \\
\hline 6 & 9.4 & Increase in glacier activity in Norway; cooling in China \\
\hline 7 & 10.3 & \\
\hline 8 & 11.1 & Transitional stage from younger dryas to boreal stage \\
\hline
\end{tabular}

The causes of the Bond events are still unclear, however, Gornitz et al. (2009) suggested that the Earth may have evolved as a component of the orbital Milanković-Bacsák cycles, which may have been affected by periodic variations in the Sun's radiant energy

\section{CONCLUSIONS}

If we want to calculate the future climate of the Earth, then, if not completely, but crucially, we need to understand the climate of the past dynamically (Major 2006). Of course, it was not the climate of the entire Earth's historical past, but the last few hundred thousand years. However, the closer we get to today's climate, the more factors have played a role, even individually, e.g. the Milanković-Bacsák cycle, the cycles of Sun activity, mountain formation or continental migration, changes in the ocean circulation, the effects of the biosphere, changes in the composition of the atmosphere of various origins, the increasing impact of human activity. The line could still be continued, but I wouldn't get to the end then. which:

The lecture should be closed by the sentence of György Bacsák (1940b), according to

Theoretical calculations therefore fit so well with the results of nature observation that Milanković's theory cannot be questioned.

Bacsák's statement is partly true, as the observations partly confirm Milanković's theory, but the researchers do not know the mechanism of action of climate change. At the same time, we cannot ignore the fact that Milutin Milanković began to mold the astronomical causes of climate change into mathematical form 100 years ago.

Furthermore, we cannot go without saying that without the clarification of György Bacsák, who was born one hundred and fifty years ago (1870), Milanković's theory would have been only one of the theories that is incomplete and inaccurate. The academic dissertation at the age of 85 meant the improvement of the theory of the Serbian scientist, who lived a hundred years (1870-1970) for less than three months. They were interdependent, which is why the Milanković-Bacsák theory is the correct name. 


\section{REFERENCES}

Bacsák Gy (1938) Letter from György Bacsák to Milutin Milanković in 1938

Bacsák Gy (1940a) Az interglaciális korszakok értelmezése II [Interpretation of interglacial eras II (in Hungarian)] Időjárás 44:62-69

Bacsák Gy (1940b) Az interglaciális korszakok értelmezése II [Interpretation of interglacial eras III (in Hungarian)] Időjárás 44:105-108

Bacsák Gy (1944) Az utolsó 600.000 év földtörténete. [The Earth history of the last 600000 years (in Hungarian)] Beszámoló a M. Kir. Földtani Intézet vitaüléseinek munkálatairól

Bacsák G (1955a) The pliocene and the pleistocene in the enlightenment of celestial mechanics (in Hungarian)

Bacsák G (1955) Pliozän- und Pleistozänzeitalter im Licht der Himmelsmechanik. Acta Geol 3:305-346

Bacsák G (1961) Überblick über das Klima der Äquatorialzone. Acta Tech 37:375-402

Bacsák G (1963) Die Ursache des bevorzugten Quadranten und ihr Zusammenhang mit den quartären Eiszeiten. Acta Tech 42:435-461

Bond G, Showers W, Elliot M, Evans M, Lotti R, Hajdas I, Bonani G, Johnson S (1999) The North Atlantic's 1-2 kyr climate rhytm: relation to Heinrich Events, Dansgaard/Oeschger cycle and the Little Ice Age. In: Clark P, Webb R, Keigwin L (1999) Mechanisms of Global Climate Change at Millennial Time Scales. Geophysical Monograph Series, Washington DC

Czelnai R (1999) A világóceán. [The world ocean (in Hungarian)] Vince Kiadó, Budapest

Gádoros M (1970) Dr. Bacsák György. [Dr. György Bacsák (in Hungarian)] Karszt- és Barlangkutató Tájékoztató 1970:3

Gornitz V (2009) Encyclopedia of paleoclimatology and ancient environments. Encyclopedia of Earth Sciences Series. Springer Science, Dordecht

Hágen A (2013) A Milanković-Bacsák-ciklus és a földtan. [The Milanković-Bacsák cycle and geology (in Hungarian)] Magyar Tudomány 174:200-205

Heinrich H (1988) Origin and consequences of cyclic ice rafting in the norttheast atlantic ocean during the past 130,000 years. Quaternary Res, 29:142-152

Major Gy (2006) A Milankovics-Bacsák elmélet és az éghajlatváltozások. [Milanković-Bacsák theory and climate change (in Hungarian)] Légkör 51:20-23

Milankovitch M (1920) Théorie mathématique des phénomenes ther-miques produits par la radiation solaire. Gauthiers-Villars, Paris. Bulletin des travaux de l'Académie des Sciences de Zagreb

Milankovitch M (1941) Kanon der Erdbestrahlung und seine Aqnwendung auf das Eiszeitenproblem. Académie royale serbe. Editions speciales 132

Milanković M (1952) Uspomene, doživljaji i saznanja iz godina 1909. do 1944. [Memories, experiences and knowledge from the years 1909 to 1944 (in Serbian)] Naučna knjiga, Beograd

Rousseau D, Sima A (2014) Abrupt changes recorded in loess sequences. Past Global Changes 22:86-87

Szarka L (2020) Titokfejtők - Mikor keletkeznek a klímakilengések? [Mystery solvers - When do climate fluctuations occur? (in Hungarian)] Természet Világa 151:361-365 